\title{
Political Parties, Party Systems and Economic Reform: Testing Hypotheses against Evidence from Postcommunist Countries*
}

\author{
JONATHAN A. TERRA** \\ Stanford University, USA
}

\begin{abstract}
Numerous scholars whose research focuses on the developed OECD countries, as well as the democratizing states of Latin America and East Asia, have attempted to answer the question "How do institutional structures affect political and economic performance in free-market, democratic societies?" These inquiries have yielded a rich and useful body of literature. By contrast, surprisingly few scholars have produced useful comparisons of political institutions and regime performance in postcommunist countries. Studies comparing postcommunist institutional performance usually suffer from an inadequate empirical treatment of cases. When studies are empirically rich and accurate, they tend to focus on a single case, and thus lack the insight of comparison. Testing hypotheses from the literature on political institutions and the political economy of democratic transitions against recent evidence from postcommunist cases allows us to gauge variations in the institutional correlates of reform in democratic systems in different regions at different levels of development. Analysis of evidence from postcommunist dual transitions, specifically from Poland and the Czech Republic, also forces us to consider the possibility that variables and causal patterns driving outcomes in one group of cases may be systematically different than variables and causal patterns in another.
\end{abstract}

Sociologický časopis/Czech Sociological Review, 2002, Vol. 38, No. 3: 277-295

\section{Introduction}

Many scholars whose research focuses on the developed OECD countries, as well as the democratizing states of Latin America and East Asia, have attempted to answer the question "How do institutional structures affect political and economic performance in freemarket, democratic societies?" These inquiries have yielded a rich and useful body of literature. By contrast, surprisingly few scholars have produced - or even attempted to produce - useful comparisons of political institutions and regime performance in postcommunist countries. In this paper I test hypotheses from the literature on the political economy of democratic transitions against recent evidence from postcommunist cases. Doing

\footnotetext{
* Partial funding for this study was provided by the National Endowment for the Humanities and the US Department of State through the International Research and Exchanges Board (IREX), and the Institute for the Study of World Politics (ISWP). The views expressed are mine and in no way represent those of the funding organizations. I would like to thank Larry Diamond for helpful comments on an earlier version of this paper. Many thanks also to Lubomír Brokl, Zdenka Mansfeldová and Michal Illner for the generous support I received from 1996-1998 at the Institute of Sociology of the Academy of Sciences of the Czech Republic in Prague.

** Direct of all correspondence to: Jonathan A. Terra, Department of Political Science, Stanford University, Stanford, CA 94305-6044, USA, e-mail: jterra@stanford.edu
} 
so with recent evidence in a paired-case comparison allows us to gauge variations in the institutional correlates of reform in democratic systems in different regions at different levels of development. Careful analysis of detailed evidence from postcommunist dual transitions, specifically from Poland and the Czech Republic, forces us to consider the possibility that variables and causal patterns driving outcomes in one group of cases may be systematically different than variables and causal patterns in another. The same evidence also suggests the need to rethink some important hypotheses from the literature on political institutions and democratic performance, and it allows us to assess the explanatory power of arguments from the literature on institutional design and economic reform.

First, I review various works on party system attributes and economic reform, while focusing on several well-known hypotheses concerning democratic institutional choice and political and economic performance. Second, I look at party system choice as a possible remedy for problems associated with political polarization and fragmentation. Third, I compare evidence from the first decade of reform in East Central Europe, focusing on party system attributes, modes of interest representation and economic reform. And fourth, I explore how political imperatives found in postcommunist systems create specific incentives for party-building strategies, and I look at the effect such strategies have on the quality of democratic political participation and the perceived legitimacy of political institutions.

\section{Party system attributes and the empirical correlates of economic reform}

As numerous authors point out [Shugart \& Carey 1992; Haggard \& Kaufman 1992; Bresser Pereira, Maraval \& Przeworski 1993; Mainwaring 1993; Stepan \& Skatch 1993; Horowitz 1993; Lijphart 1993a, 1993b; Linz 1993a, 1993b; Diamond 1999], the political institutions which structure contestation between social groups over economic reform policy, including privatization and the provision of a social safety net for citizens who are particularly vulnerable to market forces, must function properly for democracy to consolidate and for economic policies to bear fruit. In their broad-ranging study of democratization and economic adjustment in Latin America, East Asia and Turkey, Haggard \& Kaufman [1995a] find that the characteristics of party systems have profound and predictable consequences for the ability of governments to formulate and implement reform policies. Unstable and fragmented party systems, they argue, tend to complicate the negotiation of stable agreements among interest groups, while simultaneously undermining coordination within the ruling coalition, between the legislative and executive branches, and among different parts of the state apparatus [see also Haggard \& Webb 1994a]. How these effects operate depends to some extent on whether a system is parliamentary or presidential, as well as the degree of proportionality in the relationship between votes and seats.

In parliamentary systems with proportional representation (PR) rules and high proportionality, a large number of (often unstable) parties complicates coalition formation and duration. In some cases - as in Poland and the Czech Republic at various junctures since 1991 - parliamentarism with PR rules can result in weak minority governments which are unable to push through reforms authoritatively and rapidly, and which must enter into severe compromises in order to pass legislation. The case of Spain demonstrates the effects of both weak minority and strong majority government on policy making and the implementation of structural reforms: Under the first post-Franco government led by the cen- 
ter-right Center Democratic Union (UCD), the minority government had difficulty in pushing through many aspects of its economic reform program; in contrast, the Socialist Workers' Party of Spain's (PSOE) legislative majority allowed it to pass a significantly more comprehensive reform program, despite its center-left ideological position [Bermeo \& García-Durán 1994]. In addition to the problem of weak minority government, dividing cabinet posts among numerous parties in PR systems can undermine the decision-making and coordination capacity of governments. Furthermore, when party coalitions in proportional systems contain numerous members, "wars of attrition" may occur. In this scenario, observed in both developing countries and OECD states, small parties representing groups with conflicting distributional claims exercise their veto power over policy decisions, thereby complicating reform efforts [Alesina 1994, 48-51].

In presidential systems party fragmentation also increases the possibility that executives will lack the power and authority to pursue reforms. Moreover, under presidentialism small parties have fewer incentives to cooperate with governments, since there is no option to threaten early elections, and the potential for legislative blackmail is correspondingly high [Mainwaring 1993]. Irrespective of the organization of executive power, polarization and fragmentation affect the ability of governments to pursue economic reform polices in a variety of ways [Haggard \& Kaufman 1995, 170-171]. When strong leftwing, populist or movement parties are competitive in such systems, implementing reform policies becomes more difficult, since they exacerbate partisan conflict and have the power to turn labor and the popular sector against reform. In contrast, where left and populist parties are weak or absent and polarization is not a factor, coordination problems may ensue from the struggle for patronage and pork-barrel expenditures, and incentives for cooperation on behalf of reforms providing public goods decreases. The combination of fragmentation and polarization also creates opportunities for anti-reform groups to increase distributional demands on the state. This tendency increases when left or populist movements are divided and compete for the support of trade unions and other groups linked to the popular sector. The combination of fragmentation and polarization also negatively influences the ability of governments to manage economic policies by exacerbating politicalbusiness cycles [Alesina 1994, 40-47].

Cohesive party systems correlate with decidedly different patterns of policymaking. In contrast to fragmentation and polarization [Sartori 1976, 132-37], which tend to correlate, the combination of cohesion and polarization in party systems is unlikely, since strongly ideological or radical parties generally remain uncompetitive in systems with a low number of parties. Incentive structures in two-party systems also tend to push left, populist and movement parties toward the political center. In two-party systems, inter- and intraparty structures create incentives for moderation. In these systems, parties compete for the support of swing voters who occupy the middle of the political spectrum; but when politicians "crowd the center", and the median voter or powerful interests oppose reform, such competition can postpone necessary policy adjustments and may lead to stalemates. Two-party systems also correlate positively with more moderate forms of interest aggregation, since interest groups are "forced to operate in the context of an encompassing coalition in which diverse interests are represented and among which compromises must be struck" [Haggard \& Kaufman 1995a, 172]. Cohesive party systems with low polarization may also create opportunities for political patronage; when reform programs threaten patronage networks or pork-barrel programs favored by core constituents, party leaders are likely to oppose policy changes. 
In contrast with the above dilemmas, catch-all parties in cohesive, non-polarized systems have advantages in generating support for initiating reforms during economic crises. They can also bolster subsequent support for economic reform after initial policies begin to produce positive results. Catch-all parties are also less likely than left-wing parties to adopt confrontational, polarizing policy positions when reforms fail to produce the desired outcomes. Left, populist and movement parties in both fragmented and coherent party systems are more likely than catch-all parties to launch a "principled opposition" to adjustment policies, and they are "more inclined to back these appeals with support for labor activism and other forms of social protest" [ibid., 173]. Moreover, in consolidated, cohesive party systems left-wing and populist parties have incentives to broaden their electoral appeal beyond their core constituency in order to display their moderation and convince voters of their ability to govern. The left-leaning Czech Social Democratic Party (ČSSD) successfully pursued such a strategy during the 1998 parliamentary elections, despite the periodic instability of the Czech party system. This option has been less available to the Union of the Democratic Left (SLD) in Poland, since strong ideological polarization among the Polish electorate has created limits to the SLD's appeal beyond its core (but steadily expanding) left-of-center constituency (see below). In fragmented systems, however, movements toward the political center are more dangerous than in cohesive systems, since competing factions can appeal to more radical constituencies, thereby depriving moderating left or populist parties of votes.

Another potentially important advantage for governing left-wing parties in cohesive systems is that frequently observed corporatist links with organized labor and other interests threatened by economic adjustment can integrate labor into the political process "in ways that provide the basis for compromise, social pacts, and enhanced policy credibility" [idem 1994b, 17]. Corporatist links with labor in such cases may also make it easier for left-wing parties "to gain trust and negotiate compensatory agreements that permit reform to move forward" [idem, 1995a, 174]. Haggard \& Kaufman cite Chile [ibid., 257-264; cf. Arriagada Herrera \& Graham 1994, 274-276] as an example of this, while a similar pattern existed in Spain during the PSOE reforms of the 1980s [Bermeo \& García-Durán 1994], Poland (from 1993-1997), and to a considerably more limited extent in the Czech Republic (from 1998-2001).

Although predictable patterns of relationships between party system structure and the ability of policy makers to implement economic reform programs may exist, the question "Which form of government is best for coherent economic management?" appears to have no correct answer. From their study sample of 12 cases, to which they add data from 11 others, Haggard \& Kaufman conclude that "[t]here is no clear pattern differentiating presidential and parliamentary systems with respect to their capacity to manage the economy or undertake economic reform" [1995a, 352]. This result resembles Shugart \& Carey's mixed finding [1992, 38-43] more than Stepan \& Skatch's [1993] conclusion that parliamentary regimes are more durable than presidential ones (and hence offer advantages for policymakers pursuing reforms). In both crisis and non-crisis cases of economic reform, Haggard \& Kaufman conclude, "some of the central difficulties of policymaking had less to do with the executive's relationship with the legislature than with the difficulty of securing the cooperation of business and unions. Parliamentarism offers no guarantees that these relationships would be handled more effectively" [1995a, 348].

While past studies suggest that no firm or systematic answers exist concerning the relationship between party system structure and the organization of executive power, 
on the one hand, and economic reform outcomes, on the other, several findings from Haggard \& Kaufman's study stand out. First, all severe cases of hyperinflation from their data set existed under presidential or mixed presidential-parliamentary systems. Second, economic performance (particularly with regard to inflation rates) in several "pure" Westminster systems was relatively positive; this, however, may be linked less to parliamentarism than to other British institutional legacies, including strong currency boards [ibid., 353]. Third, differences in economic performance among cases appears to be linked as much to the number of parties as to whether a system is presidential or parliamentary. Fourth, all cases in which high growth coexisted with relatively low inflation, be they presidential or parliamentary, resembled two-party or dominant-party systems. Fifth, as Mainwaring [1993] also contends, the "difficult combination" of presidentialism and polarized multipartism can be especially destabilizing; party fragmentation, however, has also caused serious problems for parliamentary regimes. Sixth, party fragmentation and polarization are both cause and consequence of poor economic performance; but this hardly negates the conclusion that the nature of the party system is "a crucial variable in understanding the possibility of reconciling democratic consolidation and economic reform". Finally, while constitutional change toward parliamentarism might create incentives for politicians to build stronger organizations and extend the range of possible parliamentary alliances, switching to parliamentarism - which, in any case, has never been attempted and appears highly unlikely to occur - would entail "serious risks" if it were not accompanied by simultaneous reform of the party system and the electoral rules on which that system is based [Haggard \& Kaufman 1995a, 355]. A more realistic and hopeful strategy would instead focus on institutional reforms which "encourage the evolution of less fragmented party systems capable of aggregating interests and organizing consent” [idem 1995b, 12].

\section{Is party system choice a remedy for the problems of political polarization and fragmentation?}

Different types of party systems present different ways of dealing with the problems of political polarization and fragmentation. Two-party systems, which have a relatively strong record of macroeconomic performance and democratic stability, generally provide some role for labor, left-wing and various other minority interests, "but as distinctly junior partners to the elite-dominated centrist parties that compete for overlapping cross-class constituencies”. Most new democracies, choosing representativeness over governability and efficiency, have adopted electoral rules which discourage two-party systems. Two-party systems have the potential for becoming dominated by elite-controlled party machines, which risks "undermining coherent economic policy and...taking on exclusionary features that can weaken support for the political system as a whole”. The biggest challenge in two-party systems is to find ways of increasing participation and social compensation without resorting to institutionalized, and costly, patronage systems [idem 1995a, 355-357].

In multiethnic or regionally diverse societies, successful economic reform and democratic consolidation could possibly be achieved through consociational power-sharing agreements [Lijphart 1977] in which influential ethnic and/or regional groups secure a significant degree of autonomy. Aside from being a poor match for structural conditions in most postcommunist countries - including monoethnic Poland and the territorially and 
ethnically coherent Czech Republic ${ }^{1}$ - such systems run the risk of framing distributional issues along ethnic and/or regional lines, instead of the traditional left-right socioeconomic axis, and political mobilization campaigns are more likely to focus on distributive claims that resemble zero-sum struggles. Where one group dominates in such a system, it will likely attempt to monopolize the "political gains of office", as in Malaysia and Sri Lanka; in cases where ethnic or regional divisions are less disproportionate, "the political bargains required to sustain the system are likely to deepen fundamental economic problems", as in the case of Nigeria [Haggard \& Kaufman 1995a, 358].

In contrast with two-party and consociational systems, center-right dominant and social democrat-dominant party systems present viable and (judging from the preferences of the vast majority of regional political elites) acceptable models for the development of postcommunist states. These two options are most likely to emerge where ideological divisions have been deepened by histories of strong partisan loyalties, "working-class subcultures", or recent worker mobilization, and the shape of the party system "will turn heavily on the political allegiances of the middle classes and rural sector" [ibid., 358]. As studies of class and democratization demonstrate [Ertman 1998], a rural-middle class alliance could create the basis for a powerful conservative coalition, while a rural-working class alliance could create the basis for a social democratic coalition. Either model could serve as the institutional foundation for postcommunist states in CEE, as in other regions undergoing structural adjustment.

One possible, and less desirable, outcome of the center-right system, according to Haggard \& Kaufman, would be the emergence of a "Japanese model" in which business interests and investment are privileged over the working class, consumption and state transfers. Although this scenario would likely include strong central control over monetary and fiscal policy, it could also entail several potentially problematic developments, including the long-term relegation of labor to the status of democratic opposition, which could be reinforced by legal or political mechanisms which limit their access to power and the right to be fully "included" in systems of interest representation. Such a system resembles, in many important ways, that which evolved in the Czech Republic from 1993 to 1998. The exclusionary aspects of this model could complicate democratic consolidation and are likely to outweigh any alleged advantages in terms of promoting growth. Furthermore, a labor movement weakened by market conditions and legal or political restraints, and faced by an ideologically coherent right and a middle class unwilling to cooperate with the left, could become politically alienated as a result of its marginal status. This, in turn, could lead to political polarization and a search for quasi-authoritarian "solutions" to the problems of right-

\footnotetext{
1/ In obvious contrast to Czechoslovakia, which split into two sovereign states because of outstanding economic reform policy differences (namely the speed, scope, method and sequencing of restructuring and privatization) which fell along regional and ethnic lines and a formerly fictive Sovietstyle constitution which, when it became a valid document, was ill-suited for resolving federal-level disputes. The most significant weaknesses in this regard were: (1) relatively small shares of votes in republic-level assemblies gave parties the power to block federal-level legislation; (2) each republican prime minister had de facto veto power over the other, which discouraged policy compromise; and (3), in contrast with Western and Northern European parliamentary systems, neither the federal prime minister nor the head of state could dissolve parliament in case of an impasse. On the breakup of Czechoslovakia, see the essays in Musil [1995].
} 
left power asymmetry. Such risks are alleged to have existed at various developmental junctures in Korea, Taiwan, Turkey and Mexico [Haggard \& Kaufman1995a, 359].

By contrast, Haggard \& Kaufman argue, a social democrat-dominated party system would promote equity, welfare, employment, and could be based on a neocorporatist-style social compact in which labor exchanges wage restraint for participation in the formulation (and often implementation) of social, industrial and macroeconomic policies. When compared to center-right and perhaps even two-party-systems, they emphasize, "inclusionary features of the social democratic outcome could provide it with a relatively broad base of legitimacy and support”. But it remains unclear whether or not a sustainable social democratic coalition is possible in CEE in an era of declining union density and a rapidly growing middle class. In order to be competitive and build durable coalitions, social democratic parties "will have to incorporate small businesses, the informal sector, or new social movements whose interests with respect to gender, employment issues, and the environment often conflict with the claims of the working-class base" [ibid., 361]. Thus, a paradoxical situation arises in which the best hope for a "strategic renewal", as Kitschelt [1994a, 1994b] describes it, and the creation of an enduring social democratic coalition in an era of structural shifts in the international economy and a changing electoral marketplace appears to rest on the de-emphasis traditional of labor concerns and a search for alternative sources of electoral success. The allegedly anomalous combination of ruling social democratic parties and orthodox trade and adjustment policies has been observed in numerous cases of transition to democracy and the market, including Spain, Chile, Argentina, Poland, Hungary, and more recently, the Czech Republic. But the correlation of social democratic parties in power and liberal economic reform should not surprise us in light of the evidence that conservative fiscal and monetary policy can coexist with activist labor market and investment polices when strong links exist between governing social democratic parties and centralized, encompassing labor unions which facilitate wage restraint and working class quiescence (Garrett \& Lange 1991 [cited also in Haggard \& Kaufman 1995a, 362]).

\section{Party system attributes, interest representation and economic reform: Poland and the Czech Republic in comparative perspective}

Empirical evidence from Poland and the Czech Republic lends mixed support to hypotheses concerning party system attributes and economic reform outcomes. In some instances, evidence appears to contradict existing arguments. For example, unstable, fragmented party systems are alleged to undermine policy coordination within ruling coalitions, complicate the negotiation of compromises between policymakers and interest groups, and increase tension between the executive and legislative branches of government. But the period of extraordinary policy consensus in 1990, characterized by a broad agreement on the need for radical macroeconomic stabilization [Balcerowicz 1995], meant that the combination of fragmentation and polarization did not have the hypothesized effect of increasing anti-reformist demands until roughly one year after the implementation of stabilization polices in Poland, after the social costs of reform had already risen sharply [see Johnson \& Kowalska 1994]. By late 1993 the distributional demands of groups hurt by reform helped shape the policies of the left SLD-PSL coalition. The main 
cause of this, however, was the temporary drop in material welfare associated with macroeconomic reform, not party system fragmentation. Fragmentation instead appears to have been a secondary factor which magnified policy-induced dissatisfaction among groups which suffered disproportionately as a result of the Balcerowicz stabilization plan. More important in terms of counterevidence, the non-cooperation of trade unions belonging to an ideologically divided worker movement with links to competing parties on the right and left minimized the hypothesized impact of left or populist competition for labor support, which tends to increase distributional demands on the state and dilute reform policies. In many instances policy adjustments were consistent with the stated policy preferences of both Solidarity and the "postcommunist" OPZZ, but workers actively opposed those policies if they were associated with their partisan ideological opponents. ${ }^{2}$

While populist and partisan cycles in fragmented and polarized party systems tend to produce significant policy reversals, in both Poland and the Czech Republic, as well as many other postcommunist countries, new governments have tended to make adjustments to policies inherited from their predecessors only at the margins [see Hellman 1998]. This pattern holds even when parties are ideologically polarized, as in the case of Poland under left government from 1993 to 1997, and again under right government from 1997 to 2001. The same limited, marginal adjustments also occurred in the Czech Republic after a social democratic government assumed power in 1998 (although the Czech party system is somewhat less ideologically polarized than the Polish party system). ${ }^{3}$ Once a reform course is set in the context of dual transitions, major modifications or reversals are costly. The case of Slovakia, where the post-Mečiar coalition government which took power in 1998 had difficulty (but ultimately succeeded) in restarting a process of reform which had stalled under the preceding nationalist-populist government (BCE: The Annual 2000, 26), demonstrates this point. In addition, international pressures to maintain reforms in postcommunist countries create strong incentives to limit the scope of policy adjustments. These pressures are especially powerful in the case of EU accession states - be they part of the Luxembourg Group likely to join by 2005, or part of the larger group of countries likely to gain membership at a later date - where significant deviations threaten the process of international institutional integration.

Limitation of policy adjustments under new governments in the vast majority of postcommunist states - even when they are ideologically opposed to their predecessors to the pace or sequencing of implementation, as opposed to wholesale adjustments to policy programs, forms a marked contrast to cases of economic reform in other developing regions. Also in contrast to most (but not all) cases in the developing world, left-wing parties have initiated radical reform policies in some postcommunist countries when right-ofcenter parties stalled. The case of Hungary under the social democratic government which took power in 1994 serves as the most commonly cited example; the left-wing SLD-UP majority coalition which won the September 2001 Polish parliamentary elections also promised necessary budget restraint and economic austerity during their successful electoral campaign (WBTN, July-Sep 2001). The ČSSD-led acceleration of difficult and polit-

\footnotetext{
2/ This occurred, for example, during negotiations on the Pact On State Enterprises in 1993 when representatives of OPZZ and Solidarity refused to sit at the same table.

${ }^{3 /}$ The social democratic minority government, for example, increased the pace of economic liberalization significantly in many areas in comparison with their soi-disant neoliberal predecessors.
} 
ically-risky aspects of the privatization process in the Czech Republic also shows that leftwing parties may initiate radical reform policies in postcommunist countries when their right-of-center opponents fail to do so. ${ }^{4}$ These examples also lend indirect support to the hypothesis that incorporation into government tends to cause left parties to modify their policy positions. While this is supposed to be more likely in coherent than in fragmented party systems, in both Poland and the Czech Republic moderating left governments continued reform programs in moderately fragmented systems - in the former with a strong majority, and in the latter under the auspices of the Opposition Agreement. ${ }^{5}$

Because of the generally perceived limits of what governments can do once they assume power in postcommunist countries, the hypothesis that left parties are likely to launch a "principled opposition" to reform polices needs to be qualified. When left-wing politicians have invoked "principle" in opposing existing reform programs it has been mostly during election campaigns. Such opposition has remained mostly rhetorical, and has almost universally waned once parties of the left assumed office. Both Poland under the SLD-PSL coalition and the Czech Republic under the ČSSD government demonstrate this trend. This pattern, however, has not prevented the emergence of a strategic political blame-game. In this commonly observed scenario social democratic governments pursing the same radical reform course as their ostensibly liberal predecessors attempt to deflect criticism from their constituents who voted for reform relief by claiming they need to "sort out the mess" bequeathed to them by the previous government. And the only way of doing so, according to the typical claim, is by accelerating certain aspects of free-market reforms. This happened in Poland after the rise of the left coalition in 1993, and again after the left assumed power in 2001. The same process occurred in the Czech Republic after the rise to power of the ĆSSD in 1998 on the basis of the Opposition Agreement, and in Hungary after the Hungarian Socialist Party (MSzP) won an absolute majority in the 1994 parliamentary elections. ${ }^{6}$

The case of Poland from 1991 to 1993 confirms the hypothesis that in fragmented presidential systems executives, namely prime ministers, are likely to lack the power and authority to pursue reforms effectively. When commanding a parliamentary majority becomes difficult, and small parties possess the power of legislative blackmail - a particularly dangerous threat in systems such as Poland's which permit non-constructive votes of confidence - the pursuit of reforms which require only a moderate degree of austerity may become difficult. The Suchocka government's loss of a non-constructive vote of confi-

\footnotetext{
4/ This included, most notably, privatization of the banking, telecom and (to a lesser extent) energy sectors, as well as implementation of an incentive program for foreign investors, which lacked during the era of economic nationalism under the Klaus government.

5/ According to the Czech Opposition Agreement the ODS supported the minority ČSSD government in return for control over key parliamentary institutions (including the influential position of parliamentary speaker) and a coordinated attempt to alter electoral rules in a way which would favor the creation of a two-party system (to be dominated by ODS and C SSD). The Czech Constitutional Court judged the attempt at the latter to be unconstitutional in January 2001. The terms of the Opposition Agreement were renewed and extended to new areas of policy bargaining with the signing of the so-called Edict of Tolerance in January 2000. See LN (11 July 2001).

6/ Despite winning an absolute majority of seats in the 1994 elections the MSzP formed a coalition government with the Alliance of Free Democrats (SzDSz), which effectively allowed them to "share the blame" for economic austerity policies.
} 
dence (by a single vote) in May 1993 demonstrates this amply. After the introduction of electoral thresholds for the September 1993 elections and a resulting decline in party system fragmentation, the ability of the Polish prime minister to implement reform policies increased significantly, as the literature would predict.

Another well-known hypothesis states that left-of-center parties in cohesive party systems are likely to benefit from corporatist modes of interest bargaining which integrate labor and other groups threatened by radical reforms into the policy-making process. The case of Poland lends qualified support to this argument; the Czech case, however, lends only weak support at best. While, according to Orenstein \& Hale [2000, 18], the first Solidarity-backed governments in Poland "put surprisingly little emphasis on bringing trade unions into the policy process in an institutionalized way" at the macro-level, ${ }^{7}$ in early 1994 the left-wing coalition government successfully inaugurated macro-level tripartite bargaining in the context of a moderately fragmented party system. The range of issues discussed included state enterprise restructuring and privatization, bankruptcy protection, and state-sector wages. Although it is questionable to what degree macro-level bargaining contributed to the various policy successes of the SLD-PSL coalition, and despite the rupture between the largest participating unions (OPZZ and Solidarity) which refused to sign the same founding document, tripartism under a left-wing coalition government represented an important - although by no means the most important - element of Poland's relatively inclusive model of economic policymaking. During the 1990s this model included numerous, often informal, quasi-corporatist mechanisms incorporating both organized labor and business interests into the policymaking process through regular consultations at various ministries, as well as regular attendance during the proceedings of numerous parliamentary committees in the Sejm.

In contrast with the Polish case, attempts at corporatist bargaining in the Czech Republic date back to 1990. Although originally a result of a bargain struck between the social democratic and liberal wings of OF which liberals only grudgingly accepted [see Rutland 1992], it was the ODS-ODA-KDU-ČSL conservative coalition which used the socalled Council for Economic and Social Accord (RHSD) during the early transition period as a means of convincing labor to accept an anti-inflationary low-wage policy so reforms could continue. By 1995 trade unions within the Czech-Moravian Chamber of Trade Unions (ČMKOS) began to reject government demands concerning wage restraint, and both government and union leaders began to view one another with increasing suspicion and contempt. ${ }^{8}$ At first glance, Czech tripartism appears to lend weak confirmation to the

\footnotetext{
7/ This, of course, ignores the numerous modes of formal and informal interest representation at the firm- and sectoral-levels which did incorporate labor into the policy-making process during the entire first decade of transition in Poland. While liberal policymakers in the Mazowiecki and Bielecki governments may have feared the power of labor to reverse important stabilization measures, and therefore chose to exclude them from discussions over macroeconomic adjustment policies, to argue that labor was excluded from all important aspects of economic policymaking during the early transition process, as Orenstein \& Hale appear to do, ignores copious evidence to the contrary - particularly at the enterprise level.

${ }^{8 /}$ In an internal ČMKOS memo from 1995 one union leader expressed outrage that the Klaus government was using the system of collective bargaining to humiliate labor publicly and make worker representatives appear unreasonable. Government cynicism and abuse of the system, in his view, jus-
} 
argument that corporatist-style bargaining is likely to emerge in a cohesive party system controlled by left parties (since the Czech party system was reasonably cohesive from mid 1992 to early 1998, and corporatist structures initially evolved as a social democratic initiative prior to the breakup of OF). Upon closer examination it clearly does not. Despite its alleged role in promoting "social peace" and "including" workers in the reform process [Orenstein 1994], critical analysis and detailed interviews with participants from CMKOS show that from mid-1992 to 1998 Czech tripartism did not primarily serve as a means of integrating organized interests into the policy-making process in any meaningful way. ${ }^{9}$ The range of issues on the agenda was generally narrow, and it became even smaller as the Klaus government feared labor demands might go beyond what it deemed appropriate. Moreover, relations between "social partners" were highly asymmetrical, with the Klaus government exercising near-dictatorial control over what was supposed to be an institution aimed at making and implementing consensus-based decisions.

\section{Parties, power and policy: State control and political survival in new democracies}

As in all postcommunist dual transitions, during the initial phase of radical reform under the ODS-led coalition government the stakes of policy choices were exceptionally high, and opportunities for institutionalizing partisan influence over the economy and polity were numerous. For politicians and political parties alike, the most important variable was, and continually remained, power. Przeworski et al [1995, 40] write that "power is a natural monopoly, since it exhibits increasing returns to scale: directly, to the extent that incumbency gives advantage, and indirectly, to the extent that political power can be used to acquire economic power and economic power can be used to gain political power". This statement contains a major insight concerning the nature of influence and contestation in transitions from authoritarian rule, particularly during the early period where power configurations have yet to stabilize. In postcommunist societies, where the construction of political systems based on voter choice and economies based on private property resembles a large-scale natural experiment, the centrality of initial contestation and initial attempts to institutionalize power exceeded that in post-authoritarian states (for example, in Latin America and Southern Europe) where power configurations, although in flux, were generally much clearer and institutions - notably political parties - more developed. Understanding the relationship between political institutions and comparative regime performance under postcommunism requires consideration of this important point.

tified union withdrawal from institutionalized collective bargaining structures. The union soon thereafter quit the tripartite talks. From 1995 to 1998 Czech corporatism was effectively moribund. In the second half of 1998 the social democratic government revived the consultation process which broke down under the previous ODS-led governments.

${ }^{9 /}$ Interviews which form the basis of this claim range from a discussion with the leader of the Union of Civic Employees and member of the Board of Directors of ČMKOS during the summer of 1995, to an interview with the vice president of the steelworkers' union (KOVO) in spring 2002 (Kateřina Mandovcová, Prague, 12 September 1995; Josef Středula, Prague, 3 April 2002). Frequent meetings with government and union representatives, as well as Czech scholars writing on tripartism, confirm the assertion that the Klaus government saw tripartism as a threat to its top-down view of economic policymaking, in which bargaining among organized interests did not play a significant role. 
Domination of the state apparatus and public policy during the early transition creates the possibility of subsequent long-term increasing returns to scale from power. Members of the right-wing coalition government which exercised control over the Czech state from the birth of an independent republic in January 1993 until December 1997 understood this axiom better than their counterparts in other postcommunist countries. ${ }^{10}$ Their governing strategy focused on maximizing central control over all important aspects of economic decision making, while simultaneously erecting barriers to participation for competing interests. Rapid liquidation in 1993 of the Privatization Commission inherited from the Czechoslovak federal state, which had previously increased the breadth of opinion taken into consideration when deciding on individual privatization projects in the context of so-called small privatization [Husák 1997, 134-139], serves as just one example of this strategy. The Klaus government's strategic, cynical approach to tripartism serves as another.

The ODS-led coalition sought not to increase the participation of organized interests in the policymaking process through collective bargaining but, paradoxically, to limit it. By 1995 both government and union behavior, as well as government and union perceptions of tripartism, indicated that the goal of the Klaus government to marginalize civil society in the formulation of key economic reform policies - particularly those concerning privatization - had been largely accomplished. By "including" labor in a narrow, but publicly visible, forum where the most important distributional issues on the reform agenda were not discussed - the most significant of which was the privatization and control of state-owned assets - the coalition government effectively excluded the single largest organized interest in society from taking part in determining "who got what" during the most critical phase of the construction of Czech capitalism [Terra 2002]. The Klaus government's public proclamations during 1995 that privatization and the macroeconomic transition were by-and-large "over" 11 correspond closely with the effective collapse of corporatist policy bargaining. Viewed from this angle, an ostensibly "failed" institution appears to have served the key strategic purpose its government custodians intended.

\section{Privatization as a means of building more than markets}

Understanding the policy-related goals of ruling parties and reform outcomes in the Czech Republic requires close examination of the privatization process during the Klaus era (1992-1997). A wealth of evidence made public through investigative reports in the mass media, the admissions of key figures, and the loosening of the Czech freedom of information law after the interim Tošovský government assumed power in early 1998, reveals a pat-

\footnotetext{
10/ And the signing of the Opposition Agreement shows that power concerns continue to trump all others. If a single core value can be said to exist in the Civic Democratic Party (ODS) under the leadership of Václav Klaus, it is that the status of powerless opposition must be avoided at all costs, and a loss of influence (or, preferably, control) over state institutions is politically calamitous.

11/ According to Mandovcová, by the summer of 1995 Prime Minister Klaus made it clear to Czech unions that the most important aspects of the economic transition were "over" and there was little or no need for regular negotiations. (Interview with Kateřina Mandovcová, Prague, 12 September 1995).
} 
tern in which ruling politicians successfully used privatization as an important means of obtaining party funding. With numerically weak memberships and poorly developed legal donor networks, distributing former state assets in return for large donations served as a logical and effective means for party leaders to strengthen their organizations, and thereby ensure their future competitiveness in the struggle for political power. ODS and ODA, in particular, exploited this tactic for several years. Strong evidence exists, for example, that ODS engineered asset-for-donation quid pro quos during the sale of state shares in the telecom and steel industries, ${ }^{12}$ among others. Another significant source of illicit party contributions came from both Czech firms seeking state protection from market forces, and foreign firms seeking favorable treatment and access to local consumers. ${ }^{13}$

Illegal party financing among members of Prime Minister Klaus's ruling coalition required a complex system capable of disguising efforts to strengthen partisan organizations. This included maintaining donor anonymity by dividing large contributions into smaller sums and attributing each "gift" to numerous, and sometimes fictitious, individuals (which had the added benefit of avoiding higher taxation rates), as well as maintaining foreign bank accounts protected by secrecy laws, from which "loans" were procured when necessary. ${ }^{14}$ This strategy of organizational development and institutionalization eventually caused the collapse of the longest-reigning government in postcommunist Europe in December 1997, when revelations surfaced which detailed corruption during the privatization of a major steel mill and evidence of a linked Swiss bank account belonging to ODS..$^{15}$ The case made headlines not only for the systematic illegality it revealed, but also for the comical bungling of ODS officials during attempts at a cover-up, which included attributing large party donations made by Moravia Steel to a deceased Hungarian and a

\footnotetext{
${ }^{12 /}$ In an informal conversation in December 1998, the Czech head of the local branch of an American management consulting firm claimed to have seen "smoking gun", investigation-based evidence that a large side-payment was made by representatives of the Dutch-Swiss TelSource consortium during the privatization of the former fixed-line telephone monopoly SPT Telecom. The case of Moravia Steel making a large donation to ODS in return for guaranteed financing from a state-controlled bank and inside information on share auction pricing, which enabled a majority share purchase of a steel mill, remains the most famous case of illicit party funding (see below).

13/ ODA, for example, created a shell company called TMC based in the Virgin Islands which served as a cover for donations made by companies seeking access and anonymity. According to an investigation widely quoted in the Czech press, TMC "donated" CZK 6 million (roughly \$200,000 at the contemporaneous exchange rate) which allegedly came from Philip Morris, the First Investment Fund, and the Vitkovice steel mill. See Respekt (9 Feb 1998, 16 Feb 1998). A former chairman of ODA, who requested anonymity, verified this in spring 2002.

${ }^{14 /}$ It should be pointed out that during the period 1992-1997 KDU-ČSL benefited considerably less from the abuse of privatization policy and access-for-money schemes than did ODS and ODA. Party leaders, however, were accused of counting large donations from wealthy sponsors as smaller "member contributions" during 1996 as a means of avoiding higher taxation and preserving donor anonymity. See Respekt (1 December 1997).

15/ The Czech press covered this scandal widely. See, for example, the issues of the weekly Respekt from 1 Dec 1997, 8 Dec 1997, 9 Feb 1998, 16 Feb 1998, and 2 April 2001. For broad coverage of many aspects of the privatization and party financing scandals emerging from "the Klaus era", see also the series of articles entitled "Zlatá horečka ("The Gold Rush") published in the weekly magazine Týden from 9 February until 16 March 1998.
} 
surprised citizen of Mauritius. Subsequent investigations of the Moravia Steel case resulted in a high-profile trial in which the ODS vice chairman was accused of defrauding the state of CZK 1 million (roughly $\$ 35,000$ ) in unpaid taxes from party donations. Both founders of ODS, including former prime minister Klaus, testified during the trial. Although the defendant was exonerated in November 2000 due to a lack of evidence, the justice minister serving at the time claimed that "it's certain that a criminal act took place, and we cannot be satisfied that the guilty were not caught" (MFD, 25 May 2001).

Although it appeared that an increasingly effective legal process had undermined a once-useful means of party financing, in May 2000 Czech MPs prevented the liquidation of a system which had served them well by voting overwhelmingly to abolish taxation of party donations. Passage of the law was purposely concealed, and several prominent legislators from left to right denied knowing the real purpose of the bill, or claimed to have "forgotten" how they voted. The new law effectively shut down investigations into secret party bank accounts and ended the slow reform process which began after the collapse of the Klaus government in December 1997 (MFD, 20 April 2001).

Successful efforts to render legal a formerly forbidden (but indulged) practice and decrease the transparency of party financing contrast sharply with Polish practices. Although questionable party fundraising and cronyism in government contracts has occurred since the founding of new democratic parties began in Poland in the early 1990s, Article 11, Paragraph 2 of the Polish Constitution of 1997 emphatically states that "[t]he financing of political parties shall be open to public inspection". This constitutional provision severely complicates construction of a Czech-style system of party financing. Furthermore, relatively frequent government alternation, as well as a privatization process which involves a more diverse range of paths and practices than in the Czech Republic, has decreased opportunities for institutionalizing illicit party financing schemes. These factors also help explain the relative lack of corruption in party funding in Poland prior to the adoption of the 1997 Constitution. As a result of this system of effective disincentives, party machine-building through the distribution of state assets for side-payments has remained relatively unavailable in Poland as a feasible organizational development strategy. This reality has not, however, contributed to a significantly higher perceived legitimacy of political parties or the party system in Poland in comparison with the Czech Republic. ${ }^{16}$

\section{Conclusion}

Evidence from postcommunist countries lends mixed support to hypotheses from the literature on democratic transitions and economic reform. While the relationship between political institutions and economic reform appears at times to follow clear empirical pat-

\footnotetext{
${ }^{16 /}$ According to Eurobarometer, data from October 2001 indicate the level of trust in parties to be 12 percent in the Czech Republic, 14 percent in Poland, and 17 percent in Hungary; the average was 17 percent for EU members states and 13 percent for EU applicant countries. Levels of trust in parliament were 26 percent for the Czech Republic, 28 percent for Poland, and 44 percent for Hungary; the average was 40 percent for EU member states and 30 percent for applicant countries. See Eurobarometer 2001: Public Opinion in the Countries Applying for European Union Membership (Brussels: European Commission, March 2002) p. 24.
} 
terns, it is often subject to variation according to the pretransition regime type. Fragmentation and polarization, for example, generally complicate attempts to reform economies in any transitional setting. In postcommunist systems, however, parties of both the left and the right tend to make only marginal adjustments to policies they inherit from outgoing governments. Reform course diversions are especially unlikely in postcommunist societies due to pro-reform pressures emanating from the EU and the regional political consensus in EU applicant countries that eventual membership will bring long-awaited economic, political, social and cultural benefits.

Policy disputes in postcommunist transitions tend to revolve around the sequencing or pace of reform, not the fundamental content or direction of reform policies. This contrasts markedly with numerous earlier cases of postauthoritarian democratic transition. Left-wing parties in postcommunist countries may be more aggressively reformist than their ostensibly pro-market conservative counterparts. Furthermore, because of the relatively weak position of labor in many postcommunist states, corporatist modes of policy bargaining are unlikely to form a viable long-term option, even when left parties govern. Where corporatist policy concertation does emerge as a way of promoting consensusbuilding on behalf of reform, it is unlikely to become institutionalized and it may be abandoned by governments which seek to marginalize labor for strategic reasons.

Postcommunist parties and party systems show marked differences when compared with parties and party systems that emerged from former authoritarian systems in Latin America, Southern Europe and East Asia. In addition to unstable voter preferences which undermine the traditional class basis of party and party system organization, the historical legacy of communist rule may create ideological divisions which severely limit the coalition-building options available in a party system and it may encourage unusual and electorally risky accords such as the Czech Opposition Agreement.

With the exception of a number of organizations with roots in the communist era, political parties in postcommunist systems have relatively few resources with which to increase organizational strength. Resource deficits in newly competitive political systems create a temptation for parties which gain power during the early transition period to siphon off assets from the state as rapidly as possible as a means of survival. Such a strategy of organizational development can adversely affect economic reform, in particular booty- and patronage-generating privatization, which is likely to become less popular as it becomes identified with corrupt party practices. ${ }^{17}$ But since politically-motivated resource diversions are likely to occur before the legal and institutional bases of a market economy

\footnotetext{
${ }^{17 /}$ Public opinion data gathered in February 2002 indicated that 76 percent of Czechs believed that the economy should be under greater state control; 80 percent believed the state should maintain majority control of banks; 50 percent believed the state should prop up large enterprises; and 82 percent were dissatisfied with the privatization process. These findings represent a stunning contrast with the pro-market, pro-privatization euphoria in the Czech half of the Czechoslovak federation during the early 1990s. See $L N$ (27 March 2002). Although findings may be biased slightly upward due to the appearance of divisive electoral campaign rhetoric in the national press by late winter 2002, we can safely assume this bias to be much less significant than that resulting from a severe political crisis, as in the case of Poland during the early 1990s. Attention to such factors, although generally absent in comparative political analysis, is essential if scholars value the actual ability of data and "evidence" to support their assertions.
} 
are fully in place, recovery from this state of affairs - which negatively affects public trust in parties and parliaments, as well as economic performance - can be difficult. This pattern can be clearly observed in, among other countries, the Czech Republic and Russia [Black et al, 1999].

The stability of political systems during periods of rapid change also appears to correlate strongly with economic growth and progress along a series of economic variables. Economic progress brings clear advantages to reform projects, insofar as it improves perceptions of regime performance and legitimacy. By providing resources for targeted compensation, economic growth also decreases resentment arising from increasing income disparities among various social groups and professions. This, in turn, broadens the social base of regime support and helps institutionalize compromise. Other factors have also contributed to the stabilization of postcommunist systems. Success in achieving the stated goal of NATO membership, or making significant steps toward future membership, and progress toward full integration into the EU also reinforce the perception that postcommunist regimes have performed well. Further, in an age when democracy and the market have ascended as the favored development model and authoritarian options have been discredited, few feasible alternatives exist.

The presence of organizationally weak civil societies has also helped preserve stability in postcommunist systems. In the case where civil society has been most active in organizing opposition to various aspects of reform, namely in Poland, the broad population has arguably benefited more than anywhere else from postcommunist development. Superior growth in this case has acted as a clear counterweight to potential anti-regime threats, as it has provided the resource base for a generous (but typically inefficient) West European-style welfare state while increasing class-based support for democracy and the market among middle- and higher-income groups. ${ }^{18}$ Although some claim that the use of social compensation as a means of neutralizing opposition to reform has "demobilized" society and produced a form of exclusionary democracy [Greskovits 1998], the actual causes of variation in the level of participation across postcommunist countries are probably more related to pre-transition historical and structural factors than to strategic demobilization. This is particularly true where the inclusion or exclusion of organized labor is concerned [Terra 2002].

Irrespective of normative judgements concerning democratic outcomes, pessimistic arguments that predicted poor economic performance and widespread rejection of reform appear thoroughly discredited. Surprisingly, such arguments have been laid to rest not only by evidence in cases where progress in economic reform has been the most substantial, but also by evidence in countries where economic growth and progress have been less impressive. Arguments predicting a flood of regional poverty and subsequent widespread re-

\footnotetext{
${ }^{18 /}$ Since 1994, economic growth and successful compensation in Poland also helped limit the intensity (and, with the exception of 1999) frequency of strikes. During interviews conducted in Warsaw in 1998, former prime ministers Józef Oleksy and Włodzimierz Cimoszewicz made it clear to me how various Polish governments have deliberately used policy tools, including targeted compensation, to placate restive workers so policies could be pursued without the threat of disruption. It is also important to note that while Poland experienced an unusually high number of strikes in the early 1990s, and again in 1999, these actions have almost always focused on government policies, not on the legitimacy of democracy and the free-market system.
} 
volts against reformist governments severely underestimated the so-called political economy of patience in postcommunist societies. Citizens in postcommunist countries, it seems, are more optimistic and patient than many scholars of postcommunist systems. Concerns about consumption, economic performance, and political participation in most of the former Soviet bloc are presently not much different than in Western Europe. This should be seen as a sign of success, not failure.

The original American English usage in this article has been preserved at the request of the author.

Jonathan A. Terra received his Ph.D. in political science from Stanford University in 2002. His doctoral dissertation Influence, Assets and Democracy: Who Got What After the Fall of Communism in East Central Europe? explores political participation and economic policymaking in Poland and the Czech Republic during the 1990s.

\section{References}

Alesina, Alberto 1994. "Political Models of Macroeconomic Policy and Fiscal Reforms", in Stephan Haggard and Steven B. Webb (eds.), Voting for Reform: The Political Economy Adjustment in New Democracies. Oxford: Oxford University Press.

Arriagada Herrera, Genero and Carol Graham 1994. "Chile: Sustaining Adjustment during Democratic Transition”, in Stephan Haggard and Steven B. Webb (eds.), Voting for Reform: The Political Economy Adjustment in New Democracies. Oxford: Oxford University Press.

Balcerowicz, Leszek 1995. "Understanding Postcommunist Transitions”, in Larry Diamond and Marc Plattner (eds.), Economic Reform and Democracy. Baltimore and London: Johns Hopkins University Press.

Bermeo, Nancy and José Garciá-Durán 1994. “Spain: Dual Transition Implemented by Two Parties”, in Stephan Haggard and Steven B. Webb (eds.), Voting for Reform: The Political Economy Adjustment in New Democracies. Oxford: Oxford University Press.

Black, Bernard, Reinier Kraakman and Anna Tarassova 1999. "Russian Privatization and Corporate Governance: What Went Wrong?” Stanford: John M. Olin Program in Law and Economics Working Paper no. 178, Stanford School of Law.

Bresser Pereira, L. C., J. M. Maraval and A. Przeworski 1995. Economic Reforms in New Democracies. New York: Cambridge University Press, 1993. In Comparative Political Studies 28 (2).

Diamond, Larry 1999. Developing Democracy: Toward Consolidation. Baltimore and London: The Johns Hopkins University Press.

Ertman, Thomas 1998. "Democracy and Dictatorship in Interwar Western Europe Revisited", World Politics 50 (3), April.

Greskovits, Béla 1998. The Political Economy of Protest and Patience: East European and Latin American Transformations Compared. Budapest: Central European University Press.

Haggard, Stephan, and Robert Kaufman (eds.) 1992. The Politics of Adjustment: International Constraints, Distributive Politics, and the State. Princeton: Princeton University Press.

Haggard, Stephan and Steven B. Webb (eds.) 1994a. Voting for Reform: The Political Economy Adjustment in New Democracies. Oxford: Oxford University Press. 
Haggard, Stephan and Steven B. Webb 1994b. "Introduction", in Stephan Haggard and Steven B. Webb (eds.), Voting for Reform: The Political Economy Adjustment in New Democracies. Oxford: Oxford University Press.

Haggard, Stephen, and Robert R. Kaufman 1995a. The Political Economy of Democratic Transitions. Princeton: Princeton University Press.

Haggard, Stephen, and Robert R. Kaufman 1995b. "The Challenges of Consolidation," in Larry Diamond and Marc Plattner (eds.), Economic Reform and Democracy. Johns Hopkins University Press.

Haggard, Stephen, and Robert R. Kaufman 1997. "The Political Economy of Democratic Transitions”, Comparative Politics 29, no. 3: 263-283.

Hellman, Joel S. 1998. "Winners Take All: The Politics of Partial Reform in Post-Communist Transitions", World Politics 50, no. 2: 203-254.

Horowitz, Donald 1993. "Comparing Democratic Systems”, in Larry Diamond and Marc Plattner (eds.) The Global Resurgence of Democracy. Baltimore and London: The Johns Hopkins University Press.

Husák, Petr 1997. Budování kapitalismu v Čechách: Rozhovory s Tomášem Ježkem [Building Capitalism in the Czech Lands: Conversations with Tomáš Ježek]. Prague: Volvox Globator.

Johnson, Simon and Marzena Kowalska 1994. "Poland: The Political Economy of Shock Therapy”, in Stephan Haggard and Steven B. Webb (eds.), Voting for Reform: The Political Economy Adjustment in New Democracies. Oxford: Oxford University Press.

Kitschelt, Herbert 1994a. The Transformation of European Social Democracy. Cambridge: Cambridge University Press.

Kitschelt, Herbert 1994b. "Austrian and Swedish Social Democrats in Crisis", Comparative Political Studies, 27 (1).

Lijphart, Arend 1977. Democracy in Plural Societies. New Haven: Yale University Press.

Lijphart, Arend 1993a. "Double-Checking the Evidence", in Larry Diamond and Marc Plattner (eds.) The Global Resurgence of Democracy. Baltimore and London: The Johns Hopkins University Press.

Lijphart, Arend 1993b. "Constitutional Choices for New Democracies”, in Larry Diamond and Marc Plattner (eds.) The Global Resurgence of Democracy. Baltimore and London: The Johns Hopkins University Press.

Linz, Juan J. 1993a. "The Perils of Presidentialism”, in Larry Diamond and Marc Plattner (eds.) The Global Resurgence of Democracy. Baltimore and London: The Johns Hopkins University Press.

Linz, Juan J. 1993b. “The Virtues of Parliamentarism”, in Larry Diamond and Marc Plattner (eds.) The Global Resurgence of Democracy. Baltimore and London: The Johns Hopkins University Press.

Mainwaring, Scott 1993. "Presidentialism, Multipartism, and Democracy: The Difficult Combination”, Comparative Political Studies 26 (July).

Musil, Jiří (ed.) 1995. The End of Czechoslovakia. Budapest, New York: CEU Press.

Orenstein, Mitchell 1994. "The Czech Tripartite Council and Its Contribution to Social Peace",

MS, Yale University and IEWSS. Published in Ágh, Attila, and Gabriella Ilonszki, Parliaments and Organized Interests: The Second Steps (Budapest: Hungarian Centre for Democracy Studies, 1996).

Orenstein, Mitchell and Lisa E. Hale 1999. "Corporatist Renaissance in Postcommunist Central Europe?”, MS, Published in Christopher Candland and Rudra Sil (eds.), The Politics of Labor 
in a Global Age: Continuity and Change in Late-Industrializing and Post-Socialist Economies (Oxford: Oxford University Press, forthcoming 2002).

Przeworski, Adam et al. 1995. Sustainable Democracy. Cambridge: Cambridge University Press.

Rutland, Peter 1993. "Thatcherism, Czech-Style: Transition to Capitalism in the Czech Republic", Telos, 94 (Winter 1992/3).

Sartori, Giovanni 1976. Parties and Party Systems: A Framework for Analysis. Cambridge: Cambridge University Press.

Shugart, Matthew Soberg and John M. Carey 1992. Presidents and Assemblies: Constitutional Design and Electoral Dynamics. Cambridge University Press.

Stepan, Alfred and Cindy Skatch 1993. "Constitutional Frameworks and Democratic Consolidation: Parliamentarism Versus Presidentialism”, World Politics 46.

Terra, Jonathan, forthcoming 2002. Influence, Assets and Democracy: Who Got What After the Fall of Communism In East Central Europe? Stanford: Department of Political Science, Stanford University.

\author{
Abbreviations \\ BCE: $\quad$ Business Central Europe \\ CR: $\quad$ Czech Republic \\ ČSÚ: $\quad$ Ceský statistický úrad - Czech Statistical Office \\ GUS: $\quad$ Gtówny Urzad Statystyczny - Polish Statistical Office \\ GW: $\quad$ Gazeta Wyborcza (Poland) \\ LN: $\quad$ Lidové noviny (CR) \\ MFD: $\quad$ Mladá fronta Dnes (CR) \\ WBTN: World Bank Transition Newsletter
}


